\title{
Analisa Dan Size Optimization Jib Boom Hydraulic Crane Dengan Metode Elemen Hingga
}

\author{
Diaz Vidya Kelana dan Julendra B. Ariatedja \\ Teknik Mesin, Fakultas Teknologi Industri, Institut Teknologi Sepuluh Nopember (ITS) \\ e-mail: ariatedja@me.its.ac.id
}

\begin{abstract}
Abstrak - Crane adalah mesin alat berat yang digunakan untuk mengangkat barang dengan beban besar dan memindahkannya pada tempat yang diinginkan. Pada suatu industri kekuatan struktur pada lengan crane sangat penting. Selain itu berat dari crane juga diperhatikan karena berpengaruh pada nilai ekonomis dari suatu barang untuk bertahan di pasar persaingan industri akibat biaya material. i. Oleh karena itu optimasi dilakukan pada jib boom hydraulic crane untuk mengurangi massa. Analisa dan optimasi ukuran (size optimization) jib boom hydraulic crane untuk kapasitas 25 Ton yang meliputi lebar dan tinggi jib boom hydraulic crane dilakukan dengan software elemen hingga. Tahapan penelitian terdiri dari analisa tegangan dan defleksi dengan hand calculation, penggambaran model pada software untuk mendapatkan hasil equivalent stress dan total deformation. Selanjutnya adalah melakukan size optimization dengan response surface optimization pada model awal, model th/thl=1 dan model th/tl > 1 dengan metode NLPQL (Non-Linear Pragramming by Quadratic Lagrangian). Kemudian dilakukan analisa dan komparasi rasio tinggi/lebar setiap section dengan perhitungan rasio optimal pada Ms.Excel. Hasil yang didapat dari penelitian adalah dimensi tiga section (tinggi-lebar) dari jib boom hydraulic crane. Pada model awal geometry mass mengalami $10,26 \%$ pengurangan. Equivalent stress dan total deformation yang dimiliki oleh model awal sebesar 230,73 Mpa dan 39,907 mm. Pada model th/tll=1 dan th/tl $>1$ perubahan geometry mass, besar equivalent stress dan total deformationnya adalah $(19,39 \%, 8372,8 \mathrm{~kg}, 45,49$ mm) dan $(18,36 \%, 8744,5 \mathrm{~kg}, 40,573 \mathrm{~mm})$.
\end{abstract}

Kata Kunci-Jib Boom Hydraulic Crane, Metode Elemen Hingga, Size Optimization.

\section{PENDAHULUAN}

$\mathrm{O}$ PTIMASI struktur harus direncakan secara optimal. Struktur paling optimal adalah struktur yang memenuhi segala persyaratan yang diinginkan. Dalam industri syarat yang harus terpenuhi adalah mendapatkan struktur yang paling ekonomis. Berdasarkan variabel saat melakukan optimasi, terdapat tiga jenis yaitu topology optimization, shape optimization dan size optimization. Topology optimization adalah salah satu jenis optimasi struktur yang digunakan untuk menentukan desain optimal berdasarkan distribusi tegangan pada suatu material. Sedangkan shape optimization adalah optimasi struktur yang dilakukan berdasarkan pada variabel geometri melalui nodal tiap elemen. Pada elemen nodal terdapat lengkungan yang memiliki volume lebih kecil dari desain awal. Size optimization dilakukan berdasarkan variabel dimensi. Optimasi ini dilakukan pada ukuran lebar, tebal dan panjang struktur [1]. Hydraulic crane menggunakan sistem pneumatic hidrolik untuk pengoperasiannya. Crane ini diletakkan pada suatu titik agar tidak berpindah. Jangkauan dari hydraulic crane ini juga tidak terlalu jauh. Dalam mengangkat beban yang berat dan memindahkannya secara horizontal maupun vertikal dibutuhkan desain jib yang kuat. Namun dalam industri, kekuatan saja tidak cukup tanpa nilai ekonomis yang baik. Dalam menghasilkan nilai yang ekonomis bergantung pada salah satu faktor yaitu massa. Dengan massa yang lebih ringan, biaya material yang digunakan akan lebih sedikit, karena tergantung pada berat crane itu sendiri. Kenyataan di lapangan, jib mengalami over design.

Berdasarkan hal tersebut, penulis mencoba menganalisa equivalent stress dan total deformation yang terjadi pada jib boom hydraulic crane. Berikut ini adalah jib boom hydraulic crane yang akan dilakukan analisa dan optimasi. Ada dua tujuan utama penelitian ini antara lain: (1) mengetahui bagaimana hasil analisa stress dan besar deformasi jib boom hydraulic crane sebelum dilakukan optimasi, (2) mengetahui bagaimana hasil optimasi ukuran (size optimization) jib boom hydraulic crane yang memberikan hasil stress dan deformation terkecil.

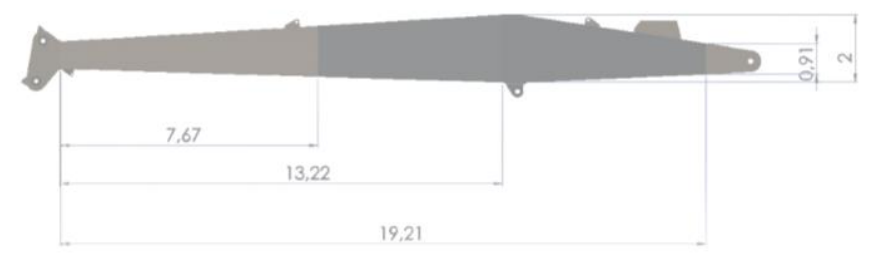

Gambar 1. Model Jib Boom Hydraulic Crane SWL 25T-20,5m.

\section{TINJAUAN PUSTAKA}

\section{A. Tegangan}

1. Tegangan Normal / Normal Stress

Tegangan normal adalah tegangan yang terjadi ketika suatu material dibebani oleh gaya aksial. Nilai dari normal stress/tegangan normal dapat didekati dengan gaya yang bekerja dibagi dengan luas area irisan. Dengan $\sigma$ adalah normal stress, $P$ adalah axial force dan A adalah luas penampang area $\sigma=\frac{P}{A}$

2. Tegangan Lengkung / Bending Stress

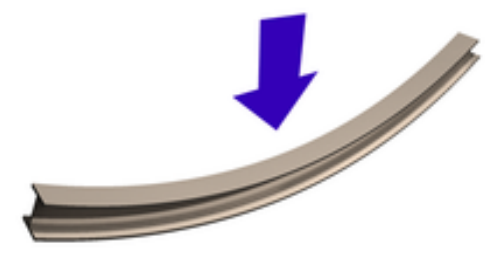

Gambar 2. Bending Stress Pada I-beam. 
Bending adalah ciri perilaku ketika material struktural ramping yang diberi beban eksternal diterapkan tegak lurus terhadap sumbu longitudinal elemen seperti ditunjukkan pada gambar 2. Perumusan bending stress ditunjukkan pada persamaan (2)

$\sigma_{\mathrm{b}}=\frac{M \cdot y}{I}$

dimana $\sigma_{\mathrm{b}}$ adalah tegangan lengkung, $\mathrm{M}$ adalah momen dan $I$ adalah momen area kedua [2].

Momen bending dapat dipengaruhi oleh besarnya momen area kedua dibagi jarak titik berat ke sumbu pusat (z). Semakin besar nilai z maka nilai tegangan akan semakin kecil. Untuk memaksimalkan z pada hollow rectangle beam dengan tebal plat horisontal dan vertikal sama, dapat digunakan persamaan (3). Dengan perbedaan tebal plat horisontal dan vertikal dapat digunakan persamaan (4) untuk memaksimalkan z jika dilakukan iterasi.

3. Tinggi section luar : $\quad H=\frac{4 t^{2}+A}{2 t\left(\frac{1}{R}+1\right)}$

Lebar section luar : $\quad B=\frac{H}{R}$

Lebar section Dalam : $\quad b=B-2 t$

Tinggi section dalam: $\quad h=H-2 t$

Maximize $\quad: \quad I / c=z=\frac{\left(\frac{H^{4}}{R}\right)-(B-2 t)(H-2 t)}{6 H}$

Lebar section Dalam : $\quad b=B-2 . t_{b}$

4. Tinggi section dalam: $\quad h=H-2 t_{h}$

Rasio section dalam : $\quad R_{d}=\frac{t h}{t b}$

Tinggi section luar : $\quad H=\frac{\frac{4 t h^{2}}{R d}+A}{2 \cdot t h \cdot\left(\frac{1}{R d}+\frac{1}{R l}\right)}$

Maximize $\quad: \quad I / c=z=\frac{\left(B H^{3}-h^{3}\right)}{6 H}$

\section{METODOLOGI PENELITIAN}

\section{A. Analisa Tegangan Dan Defleksi (Hand Calculation)}

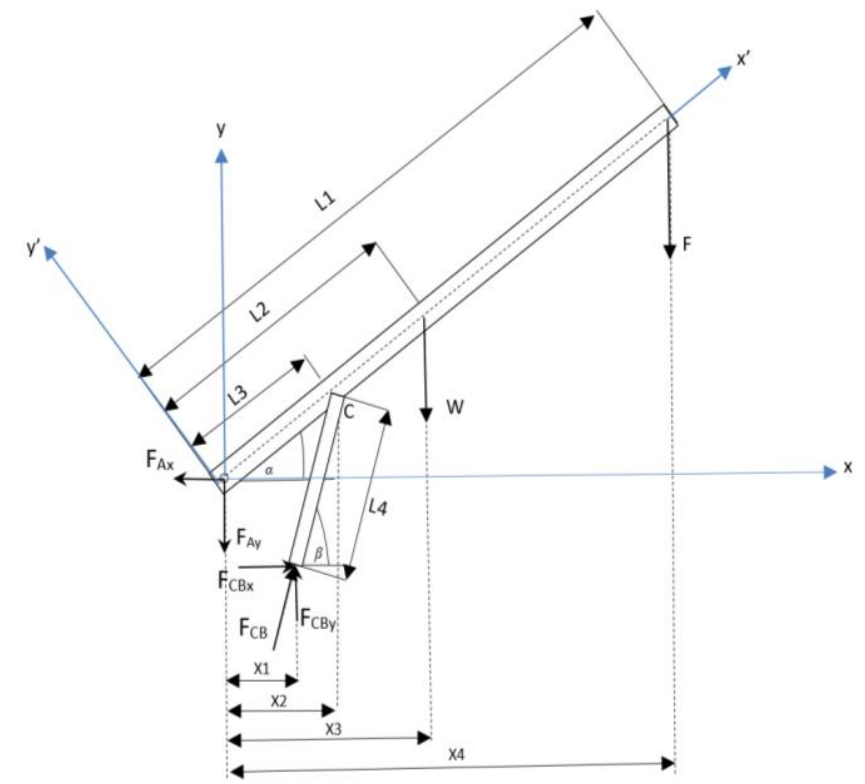

Gambar 3. Free Body Diagram Gaya-Gaya pada Jib Boom Hydraulic Crane.
Analisa tegangan dan defleksi dengan hand calculation dilakukan dengan tujuan melakukan verifikasi yang akan dibandingkan dengan hasil simulasi equivalent stress dan total deformation pada software. Dalam menganalisa stress dan total deformation dibutuhkan beberapa data yang harus dicari yaitu besar gaya reaksi, momen, momen area kedua hingga persamaan defleksi.

\section{Perhitungan Gaya-Gaya Pada Jib Boom}

Tabel 1.

Keterangan Dimensi Jib Boom Hydraulic Crane Pada Gambar 3.3.

\begin{tabular}{ccc}
\hline \hline No & Keterangan & Dimensi $(\mathrm{m})$ \\
\hline 1 & L1 & 19,21 \\
2 & L2 & 9,605 \\
3 & L3 & 5,99 \\
4 & L4 & 6,982 \\
5 & L5 & 2,335 \\
6 & $\mathrm{X} 1$ & $5,99 \cos \alpha-6,982 \cos \beta$ \\
7 & $\mathrm{X} 2$ & $5,99 \cos \alpha$ \\
8 & $\mathrm{X} 3$ & $9,605 \cos \alpha$ \\
9 & $\mathrm{X} 4$ & $19,21 \cos \alpha$ \\
10 & $\mathrm{\gamma}$ & $90^{\circ}-\beta+\alpha$ \\
\hline \hline
\end{tabular}

$\sum M_{C}=0$

$0 \quad=F_{A y^{\prime}} \cdot L 3-W \cos \alpha\left(L_{2}-L_{3}\right)-F \cos \alpha\left(L_{1}-L_{3}\right)$

$F_{A y^{\prime}}=\frac{W \cos \alpha(L 2-L 3)+F \cos \alpha(L 1-L 3)}{L 3}$

$$
\begin{aligned}
& \sum_{0} M_{A}=0 \\
& F_{C B}=\frac{W \cos \alpha(L 2)+F \cos \alpha(L 1)}{\cos \gamma(L 3)}
\end{aligned}
$$

$\sum F X=0$

$0 \quad=F_{A x^{\prime}}+F_{C B} \cdot \sin \gamma-W \sin \alpha-F \sin \alpha$

$F_{A x^{\prime}}=-F_{C B} \cdot \sin \gamma+W \sin \alpha+F \sin \alpha$

Dimana $F_{A x^{\prime}}=F_{A X} \cdot \cos \alpha$ dan $F_{A Y^{\prime}}=F_{A y \cdot} \cdot \cos \alpha$.

Dengan mensubstitusikan $\alpha=15^{\circ}, \beta=39^{\circ}$ dan $\gamma=66^{\circ} \mathrm{ke}$ dalam persamaan (5) hingga (7), akan didapatkan besarnya nilai $\mathrm{F}_{\mathrm{Ax}}{ }^{\prime}=-1.717 .444,7 \mathrm{~N}, \mathrm{~F}_{\mathrm{Ay}}{ }^{\prime}=648,005,8 \mathrm{~N}, \mathrm{~F}_{\mathrm{Ax}}=-1.765 .217,8$ $\mathrm{N}, \mathrm{F}_{\mathrm{Ay}}=666.419 \mathrm{~N}$ dan $\mathrm{F}_{\mathrm{CB}}=2.113 .479,5 \mathrm{~N}$.

2. Perhitungan Momen Area Kedua Jib Boom

Perhitungan momen area kedua menggunakan persamaan (3). Dilakukan penyederhanaan model jib boom dalam perhitungan. Hal ini dilakukan untuk mempermudah perhitungan secara hand calculation. Berikut ini adalah potongan section pangkal, tengah dan ujung pada jib untuk melakukan perhitungan

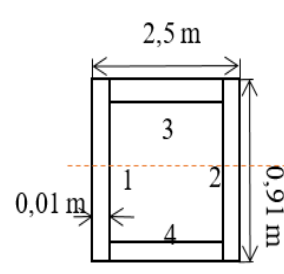

(a)

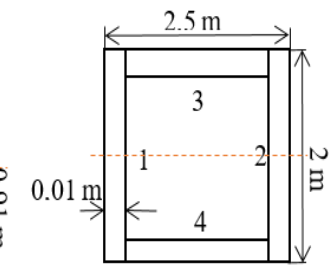

(b)

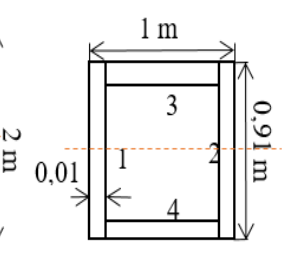

(c)
Gambar 4. Potongan section (a): Pangkal, (b): Tengah, (c) : Ujung Jib Boom Hydraulic Crane (Without scale). 
Dengan menggunakan perumusan (3) didapatkan momen area kedua untuk setiap sectionnya. Besarnya momen area kedua pada section pangkal adalah $0,02666 \mathrm{~m}^{4}$, section tengah sebesar $0,03874 \mathrm{~m}^{4}$ dan $0,00281 \mathrm{~m}^{4}$ untuk section ujung. Sehingga $\mathrm{I}_{\mathrm{PANGKAL}}+\mathrm{I}_{\mathrm{TENGAH}}+\mathrm{I}_{\mathrm{UJUNG}}=0,06821 \mathrm{~m}^{4}$

3. Perhitungan Defleksi Jib Boom

Metodologi awal dalam pengerjaan studi ini adalah penggambaran diagram benda bebas dari gaya-gaya luar yang terjadi pada kondisi kesetimbangan, kemudian mencari persamaan defleksi dengan persamaan (4). [3]

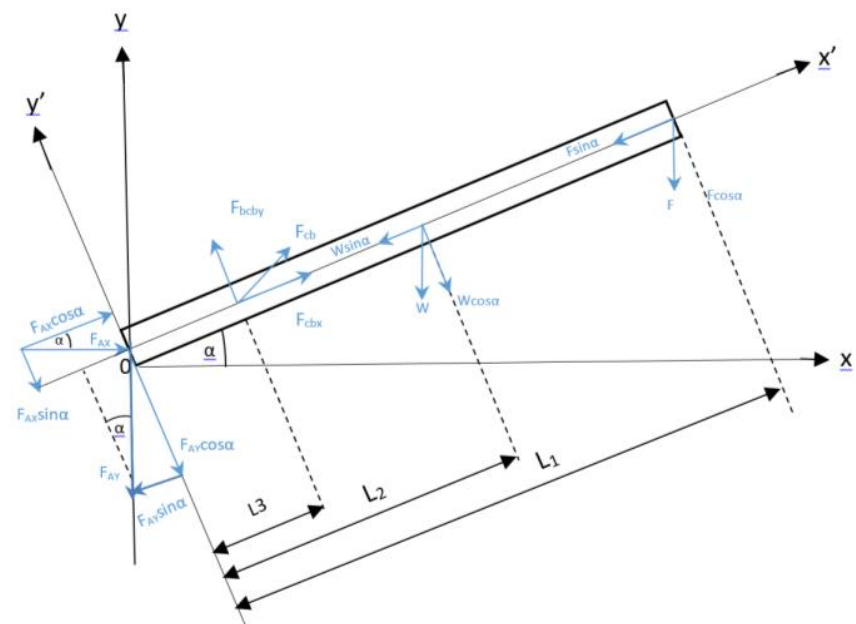

Gambar 5. Free Body Diagram Jib Boom Hydraulic crane.

$M\left(x^{\prime}\right)=-F_{A x \cdot} \sin \alpha(x-0)^{1}-F_{A y} \cdot \cos \alpha(x-0)^{1}+F_{C B x}\left(x-L_{3}\right)^{1-}$ $\left(-F_{C B y}\right)\left(x-L_{3}\right)^{1}-W \cos \alpha\left(x-L_{2}\right)^{1}$

$M\left(x^{\prime}\right)=-F_{A x \cdot} \sin \alpha(x-0)^{1}-F_{A y \cdot} \cdot \cos \alpha(x-0)^{1}+F_{C B x}(x-5,99)^{1-}$ $\left(-F_{C B y}\right)(x-5,99)^{1}-W \cos \alpha\left(x-L_{2}\right)^{1}$

$E I \cdot \frac{d^{2} y}{d x^{2}}=M\left(x^{\prime}\right)$

$E I \cdot \frac{d^{2} y \prime}{d x^{2}}=-F_{A x} \cdot \sin \alpha \cdot x-F_{A y} \cdot \cos \alpha \cdot x+F_{C B x}(x-5,99)^{1}-\left(-F_{C B y}\right)(x-5,99)^{1}$ $-W \cos \alpha\left(x-L_{2}\right)^{1}$

$E I \cdot \frac{d y^{\prime}}{d x}=-F_{A x \cdot} \sin \alpha \cdot \frac{1}{2} X^{2}-F_{A y \cdot} \cos \alpha \cdot \frac{1}{2} X^{2}+\frac{F C B x}{2}(x-5,99)^{2}+\frac{F C B y}{2}(x-$ $5,99)^{2}-\frac{W \cdot \cos \alpha}{2}(x-9,605)^{2}+C 1$

$E I \cdot y^{\prime}=\frac{-F a x \cdot \sin \alpha}{6} x^{3}-\frac{F a y \cdot \cos \alpha}{6} x^{3}+\frac{F C B x}{6}(x-5,99)^{3}+\frac{F C B y}{6}$ $(x-5,99)^{3}-\frac{W \cdot \cos \alpha}{6}(x-9,605)^{3}+C 1 x+C 2$

Mencari konstanta integrasi $\mathrm{C} 1$ dan $\mathrm{C} 2$ digunakan kondisi batas sebagai berikut

Kondisi batas I,

$\mathrm{y}^{\prime}=0$ pada $\mathrm{x}^{\prime}=0 \quad \mathrm{x}<\mathrm{a}, \quad(\mathrm{x}-\mathrm{a})=0$

$0=0-0-0+0+0+0+\mathrm{C} 2$

$\mathrm{C} 2=0$

Kondisi batas II,

$\mathrm{y}^{\prime}=0$ pada $\mathrm{x}=5,99 \mathrm{~m}$

$0=\frac{-F A x \cdot \sin \alpha}{6}(5,99)^{3}-\frac{F A y \cdot \cos \alpha}{6}(5,99)^{3}+0+C 1(5,99)$

$0=-35,82\left(F_{A x} \cdot \sin \alpha \cdot x-F_{A y \cdot} \cos \alpha \cdot x\right)-C 1(5,99)$

$C 1=5,97\left(F_{A x} \cdot \sin \alpha \cdot x-F_{A y} \cdot \cos \alpha \cdot x\right)-2640057,9$

Maka setelah konstanta integrasi pada persamaan (9) dan (10) di substitusikan ke dalam persamaan (8) sehingga persamaan menjadi seperti berikut

$E I y^{\prime}=\frac{1}{6}\left(-F_{A x \cdot} \sin \alpha \cdot x^{3}-F_{A y \cdot} \cdot \cos \alpha \cdot x^{3}+F_{C B x}(x-5,99)^{3}+F_{C B y}\right.$

$(x-5,99)^{3}-\frac{W \cdot \cos \alpha}{6}(x-9,605)^{3}+5,97\left(F_{A x} \cdot \sin \alpha \cdot x-F_{A y} \cdot \cos \alpha \cdot x\right)$

$-2640057,9$

Nilai defleksi maksimum dapat dicari dari persamaan (11) yang telah didapat. Defleksi masksimum terjadi pada $\mathrm{x}=19,21 \mathrm{~m}$ sehingga didapat $0,042 \mathrm{~m}$ atau $42 \mathrm{~mm}$.

- Perhitungan Tegangan

Langkah awal untuk menghitung tegangan (stress) pada jib boom hydraulic crane adalah menghitung momen pada tiap titik dengan analisa bidang vertikal

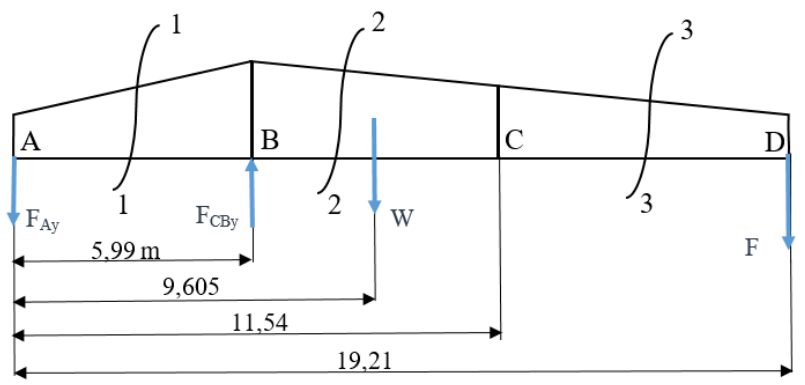

Gambar 6. Analisa bidang vertikal dengan metode potongan.

Setelah didapatkan momen pada setiap titik pada beam kemudian menggunakan persamaan (2) untuk didapatkan tegangan pada titik A, B dan C pada jib boom hydraulic crane. Tegangan pada titik B didapatkan sebesar 206,08 Mpa dan pada titik D adalah 29,8 Mpa. Tegangan pada titik B merupakan tegangan maksimum.

B. Analisa Equivalent Stress dan Total Deformation pada Software Elemen Hingga.

Analisa dilakukan sebelum dilakukan size optimization. Dengan melakukan analisa diawal akan dapat dibandingkan dengan hasil yang teroptimasi. Equivalent stress maksimum terjadi pada section tengah jib sebesar 258,89 Mpa. Total Deformation maksimum terjadi pada ujung jib sebesar 40,652 $\mathrm{mm}$

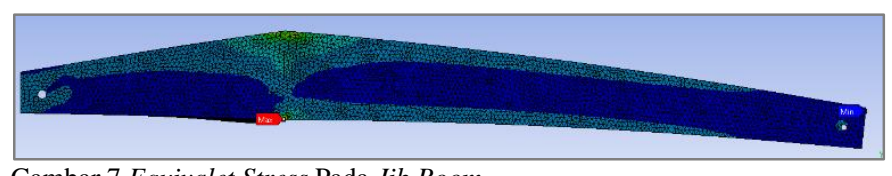

Gambar 7.Equivalet Stress Pada Jib Boom.

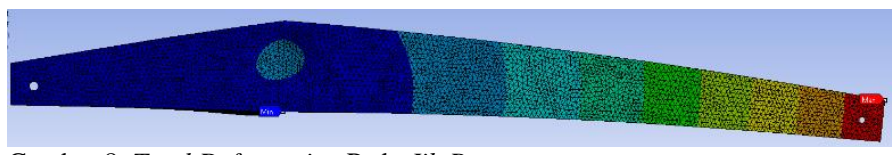

Gambar 8. Total Deformation Pada Jib Boom.

Berdasarkan hasil simulasi pada software hasil hand calculation pada equivalent stress terjadi perbedaan sebesar $20,3 \%$ dan $15 \%$ pada total deformation. Hal ini menunjukkan bahwa hasil pada software mendekati yang sebenarnya. 


\section{Size Optimization}

Sebelum dilakukan optimasi, terdapat tiga besaran utama optimasi yang harus ditentukan yaitu design variable, objective function, dan constraint yang harus ditentukan terlebih dahulu [3]. Persamaan tiga besaran utama dituliskan seperti berikut ini 1. Design variables

Design variables pada penelitian tugas akhir ini adalah lebar dan tinggi jib boom hydraulic crane pada setiap cross section. Dengan terdapat tiga design variables untuk lebar dan tiga design variables untuk tinggi. Sehingga terdapat 6 design variables yaitu lebar 1, lebar 2, lebar 3, tinggi 1, tinggi 2, tinggi 3 dan dapat dituliskan seperti persamaan berikut ini

$\mathrm{X}=$ Lebar cross section 1 : H5-P6 (Parameter symbol pada software)

Tinggi cross section 1: V6-P6 (Parameter symbol pada software)

Lebar cross section 2 : H18-P5 (Parameter symbol pada software)

Tinggi cross section 2: V19-P5 (Parameter symbol pada software)

Lebar cross section 3 : H9-P7 (Parameter symbol pada software)

Tinggi cross section 3: V6-P7 (Parameter symbol pada software)
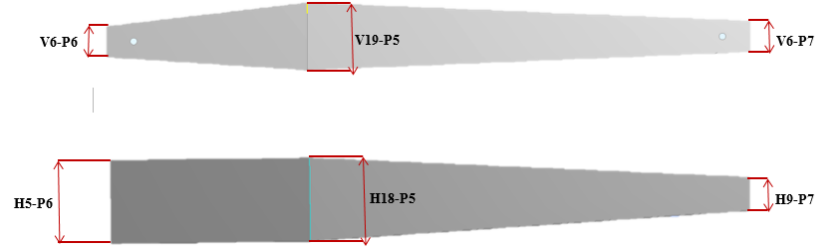

Gambar 9. Ilustrasi input parameter (design variables) Pada Jib Boom

\section{Objective Function}

Objective function merupakan tujuan dari dilakukannya optimasi, massa jib menjadi objective function yang harus diminimalkan.

$\operatorname{Min} \mathrm{f}(\mathrm{x})$,

$\mathrm{f}(\mathrm{x})$ = Massa Jib Boom Hydraulic Crane ( $\mathrm{kg})$

Massa $=\rho \times$ Volume Total

Massa $=\rho \times(V 1+V 2+V 3)$

Massa $=\rho \times[(H 5 x V 6 x t)+(H 18 x V 19 x t)+(H 9 x V 6 x t), \mathrm{kg}$

Constraints

Inequality constraint :

Subject to

Equivalent Stress $\quad: \sigma_{\text {arranged }} \leq \sigma_{\text {allowed }}$

Total Deformation $\quad: \delta_{\text {arranged }} \leq \delta_{\text {allowed }}$

Size Constraints : $2 \leq H 5-P 6 \leq 2,75 \mathrm{~m}$

$2 \leq H 18-P 5 \leq 2,75 \mathrm{~m}$

$0,8 \leq \mathrm{H} 9-\mathrm{P} 7 \leq 1,1 \mathrm{~m}$

$0,8 \leq \mathrm{V} 6-\mathrm{P} 6 \leq 1 \mathrm{~m}$

$1,8 \leq V 19-P 5 \leq 2,2 \mathrm{~m}$

$0,8 \leq V 6-P 7 \leq 1,1 \mathrm{~m}$

\section{PEMBAHASAN}

Size Optimization menggunakan fitur Response Surface Optimization pada Workbench. Dengan menentukan upper dan lower bound pada setiap desain variabel. Kemudian menentukan objective function dan constraints. Metode optimasi menggunakan NLPQL yang dilakukan dengan 100 iterasi. Hasil optimasi telah convergen dengan 224 evaluasi.

Tabel 2.

Candidate Point Hasil Size Optimization

\begin{tabular}{|c|c|c|}
\hline & Candidate Point 1 & Candidate Point 2 \\
\hline P2 - Plane6.V6 (m) & 0,89137 & 0,89773 \\
\hline P1 - Plane6.H5 (m) & 2 & 2 \\
\hline P3 - Plane $5 . \mathrm{H} 18(\mathrm{~m})$ & 2,1066 & 2,1153 \\
\hline P4 - Plane $5 . V 19(\mathrm{~m})$ & 1,9387 & 1,936 \\
\hline P5 - Plane7.H9 (m) & 0,85434 & 0,87504 \\
\hline P6 - Plane7.v6 (m) & 0,88658 & 0,89765 \\
\hline P7 - Equivalent Stress Maximum (MPa) & 237,3 & 茫 230,73 \\
\hline P8 - Total Deformation Maximum (mm) & 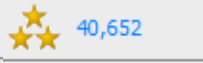 & 39,907 \\
\hline P9 - Geometry Mass (kg) & えれ 9276,4 & ઔむ 9321,2 \\
\hline P10 - Safety Factor Minimum & 1,5044 & 1,528 \\
\hline
\end{tabular}

Pada Tabel 2 dapat diketahui bahwa geometry mass yang dihasilkan dari optimasi ukuran adalah 9276,4 $\mathrm{kg}$ untuk kandidat 1 dan 9231,2 kg untuk kandidat 2. Geometry mass mengalami perubahan sebesar $10,7 \%$ untuk canditate point 1 dan dan 10,26\% untuk candidate point 2. Kandidat terbaik dimiliki oleh candidate point 1 dengan equivalent stress sebesar 237,3 Mpa dan total deformation 40,652 mm.

\section{A. Size Optimization Lanjut}

Mengacu pada hasil optimasi sebelumnya, penulis melakukan penelitian kembali dengan melakukan optimasi Lanjut. Optimasi lanjut dilakukan dengan merubah tebal dari plat vertikal dan horisontal jib boom hydraulic crane yang tersedia di penjualan dengan material yang sama. Hal ini dilakukan untuk lebih mengurangi massa dari jib dengan kekuatan yang tetap baik dan tidak melebihi batas kekuatan dari material. Secara teoritis, semakin tebal plat yang digunakan maka nilai dari I/C (momen area kedua/ jarak terjauh dari sumbu utama) akan semakin besar [4].

Tabel 3.

Perbandingan Pengaruh Tebal Plat Terhadap Output Parameter Size Optimization

\begin{tabular}{|c|c|c|c|c|c|c|c|}
\hline \multirow{2}{*}{ Model } & $\begin{array}{c}\text { th } \\
\text { (atas- } \\
\text { bawah) } \\
\text { mm }\end{array}$ & $\begin{array}{c}\text { tl } \\
\text { (kanan- } \\
\text { kiri) } \\
\text { mm }\end{array}$ & $\begin{array}{c}\text { Equivalent } \\
\text { Stress } \\
\text { (Mpa) }\end{array}$ & $\begin{array}{c}\text { Total } \\
\text { Deformation } \\
\text { (mm) }\end{array}$ & $\begin{array}{c}\text { Safety } \\
\text { Factor }\end{array}$ & $\begin{array}{c}\text { Geometry } \\
\text { Mass (kg) }\end{array}$ & $\begin{array}{c}\text { Ratio } \\
\text { th/tl }\end{array}$ \\
\hline \multirow{2}{*}{$\begin{array}{c}\text { Model } \\
\mathbf{t}_{\mathbf{H}} / \mathbf{t}_{\mathbf{L}}=\mathbf{1}\end{array}$} & 8 & 8 & 300,95 & 48,628 & 0,8307 & 8250,7 & 1 \\
\cline { 2 - 8 } & 10 & 10 & 257,97 & 40,946 & 1,41 & 10388 & 1 \\
\hline \multirow{2}{*}{$\begin{array}{c}\text { Model } \\
\mathbf{t}_{\mathbf{H}} / \mathbf{t}_{\mathbf{L}}>\mathbf{1}\end{array}$} & 12 & 12 & 217,83 & 31,991 & 1,1477 & 12347 & 1 \\
\cline { 2 - 8 } & 12 & 10 & 214,32 & 34,246 & 1,1665 & 11486 & 1,2 \\
\cline { 2 - 8 } & 12 & 6 & 236,41 & 41,76 & 1,0575 & 10144 & 1,5 \\
\hline
\end{tabular}

Berdasarkan Tabel 3 tersebut menjadi acuan untuk melakukan size optimization dengan tebal plat yang berbeda. Tebal yang dipilih adalah model th/tl $=1$ dengan $8 \mathrm{~mm}$. Tebal plat yang digunakan dengan model th/tl $>1$ adalah th $=12 \mathrm{~mm}$ dan $\mathrm{tl}=6 \mathrm{~mm}$. Pemilihan ini berdasarkan masa yang paling ringan dengan equivalent stress dibawah batas kekuatan material. 
Tabel 4 .

Perbandingan Hasil Optimasi Ketiga Model

\begin{tabular}{|c|c|c|c|c|c|c|c|c|c|}
\hline \multirow{3}{*}{\multicolumn{2}{|c|}{ Model }} & \multirow{3}{*}{$\begin{array}{c}\text { th } \\
(\mathrm{mm})\end{array}$} & \multirow{3}{*}{$\underset{(\mathrm{mm})}{\mathrm{tl}}$} & \multicolumn{6}{|c|}{ Section } \\
\hline & & & & \multicolumn{2}{|c|}{ Pangkal (m) } & \multicolumn{2}{|c|}{ Ujung (m) } & \multicolumn{2}{|c|}{ Ujung (m) } \\
\hline & & & & tinggi & lebar & $\operatorname{tin}$ & lebar & tin & \begin{tabular}{l|l} 
gi & lebar \\
\end{tabular} \\
\hline \multicolumn{2}{|c|}{$\begin{array}{c}\text { Awal } \\
\text { (sebelum } \\
\text { optimasi) }\end{array}$} & 10 & 10 & 0,91 & 2,5 & 2 & 2,5 & 0 & 1 \\
\hline \multicolumn{2}{|c|}{$\begin{array}{c}\text { Awal } \\
\text { (Optimasi) }\end{array}$} & 10 & 10 & 0,89 & 2 & 1, & 2,1 & 0 & 0,85 \\
\hline \multicolumn{2}{|c|}{ th $/ \mathrm{tl}=1$} & 8 & 8 & 1 & 2,26 & 2,1 & 2,36 & 1 & 1,09 \\
\hline \multicolumn{2}{|c|}{$\mathrm{th} / \mathrm{t} 1>1$} & 12 & 6 & 0,819 & 2 & 2,1 & 2 & 0,8 & 0,9 \\
\hline \multirow[b]{2}{*}{ No } & \multirow{2}{*}{\multicolumn{2}{|c|}{ Model }} & \multicolumn{7}{|c|}{ Output Parameter } \\
\hline & & & \multicolumn{2}{|c|}{$\begin{array}{l}\text { Geometry } \\
\text { Mass (kg) }\end{array}$} & \multicolumn{2}{|c|}{$\begin{array}{c}\text { Equivalent } \\
\text { Stress (Mpa) }\end{array}$} & \multicolumn{2}{|c|}{$\begin{array}{c}\text { Total } \\
\text { Deformation } \\
(\mathrm{mm})\end{array}$} & $\begin{array}{l}\text { Safety } \\
\text { Factor }\end{array}$ \\
\hline 1 & \multicolumn{2}{|c|}{$\begin{array}{c}\text { Awal } \\
\text { (Sebelum } \\
\text { Optimasi) }\end{array}$} & \multicolumn{2}{|c|}{10388} & \multicolumn{2}{|c|}{258,89} & \multicolumn{2}{|c|}{40,652} & 1,4 \\
\hline 2 & \multicolumn{2}{|c|}{$\begin{array}{c}\text { Awal } \\
\text { (Sesudah } \\
\text { Optimasi) }\end{array}$} & \multicolumn{2}{|c|}{9276,4} & \multicolumn{2}{|c|}{237,3} & \multicolumn{2}{|c|}{40,652} & 1,5 \\
\hline 3 & \multicolumn{2}{|c|}{ th $/ \mathrm{tl}=1$} & \multicolumn{2}{|c|}{8372} & \multicolumn{2}{|c|}{297,65} & \multicolumn{2}{|c|}{45,49} & 1,5003 \\
\hline 4 & \multicolumn{2}{|c|}{ th/t $1>1$} & 848 & & & & 40,5 & & 1,5 \\
\hline & \multirow{2}{*}{\multicolumn{2}{|c|}{ Model }} & \multicolumn{7}{|c|}{ Output Parameter } \\
\hline No & & & & $\begin{array}{l}\text { eometry } \\
\text { Mass }\end{array}$ & & \multicolumn{2}{|c|}{$\begin{array}{c}\text { Equivalent } \\
\text { Stress }\end{array}$} & \multicolumn{2}{|c|}{$\begin{array}{c}\text { Total } \\
\text { Deformation }\end{array}$} \\
\hline 1 & & wal & & $0388 \mathrm{~kg}$ & & 58,8 & Mpa & 40, & $52 \mathrm{~mm}$ \\
\hline & & & & & $\mathrm{Pe}$ & uba & an $(\%)$ & & \\
\hline 2 & $\begin{array}{r}\mathrm{A} \\
(\mathrm{Opt}\end{array}$ & $\begin{array}{l}\text { wal } \\
\text { imasi) }\end{array}$ & & $10,70 \%$ & & $-8,3$ & & & $0 \%$ \\
\hline 3 & & $\mathrm{t}=1$ & & $19,39 \%$ & & 14, & & & $65 \%$ \\
\hline 4 & & $\mathrm{t} 1>1$ & & $18,36 \%$ & & 1,2 & & & $18 \%$ \\
\hline
\end{tabular}

Dari ketiga model yang telah dilakukan size optimization dapat dijadikan desain baru kedepannya. Namun yang paling maksimum hasilnya adalah model th/tl=1. Dengan massa yang lebih ringan dapat menerima beban sebesar 25 Ton. Dan equivalent stress yang terjadi tidak melebihi batas kekuatan material.

\section{B. Komparasi Hasil Size Optimization}

Dalam melakukan perbandingan rasio tinggi/lebar setiap section pada jib boom dari hasil software dilakukan dengan perhitungan pada Microsoft Excel. Perhitungan rasio dilakukan untuk mengetahui berapa perbandingan tinggi/lebar optimal pada rectangle hollow beam sebagai section dari jib boom hydraulic crane. Pencarian rasio optimal dilakukan dengan cara mencari I/c yang maksimum dengan A (luas) konstan.

Perbandingan Rasio Tinggi-Lebar Section (Pangkal, Tengah, Ujung) Pada Model Awal (Teroptimasi) dan Model th/tl=1

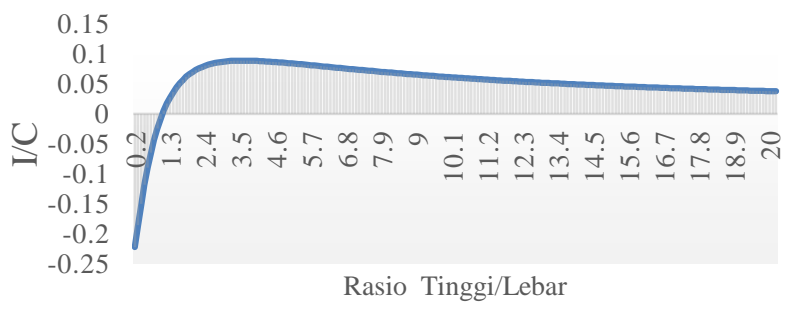

Gambar 10. Rasio Tinggi/Lebar vs I/c Section Pangkal Jib Pada Model Awal $(\mathrm{Th}=\mathrm{Tl}=10 \mathrm{~mm}$ ) Setelah Optimasi
Tabel 5 .

Perbandingan Rasio Tinggi-Lebar pada Jib Boom Model Awal (Ter-optimasi)

\begin{tabular}{|c|c|c|c|}
\hline \multirow{2}{*}{ Section } & ANSYS / Excel & Rasio th/tl & $\mathbf{Z}=\mathbf{I} / \mathbf{c}$ \\
\hline \multirow{2}{*}{ Pangkal } & Excel & 2,4 & 0,806 \\
\cline { 2 - 4 } & ANSYS & 0,44 & 0,0543 \\
\hline \multirow{2}{*}{ Tengah } & Excel & 2,25 & 2,01378 \\
\cline { 2 - 4 } & ANSYS & 0,92 & 1,43248 \\
\hline \multirow{2}{*}{ Ujung } & Excel & 3,6 & 0,08964 \\
\cline { 2 - 4 } & ANSYS & 1,037 & 0,002 \\
\hline
\end{tabular}

Hasil pada tabel 5 didapatkan presentase pada section pangkal hanya mencapai 6,73\% dari rasio optimal. Tabel 5 juga menunjukkan rasio Tinggi-Lebar pada section tengah dan ujung. Dapat diketahui bahwa pada section B rasio optimal yang didapatkan pada Ms.Excel adalah 2,25. Sedangkan rasio Tinggi-Lebar (V19-H18) yang didapatkan dari optimasi software adalah 0,92. Hasil antara keduanya sangat jauh berbeda. Rasio dengan 0,92 mencapai $71,13 \%$ dari ratio optimal. Pada section $\mathrm{C}$ berdasarkan perhitungan menggunakan Ms.Excel didapatkan rasio optimal 3,6 yang menghasilkan I/c 0,08964. Sedangkan hasil software memberikan rasio (V6-H9) 1,037 dengan $\mathrm{I} / \mathrm{c}$ adalah 0,002 . Rasio yang diberikan oleh software mencapai hanya $2,23 \%$ dari rasio optimal yang dihitung dengan Ms.Excel.

Tabel 6.

Perbandingan Rasio Tinggi/Lebar Section pada Jib Boom Model th/tl=1

\begin{tabular}{|c|c|c|c|}
\hline Section & $\boldsymbol{A N S Y S} /$ Excel & Rasio th/tl & $\mathbf{Z}=\mathbf{I} / \mathbf{c}$ \\
\hline \multirow{2}{*}{ Pangkal } & Excel & 2,4 & 0,804898 \\
\cline { 2 - 4 } & ANSYS & 0,44 & 0,042424 \\
\hline \multirow{2}{*}{ Tengah } & Excel & 2,2 & 2,0124 \\
\cline { 2 - 4 } & ANSYS & 0,907 & 1,413581 \\
\hline \multirow{2}{*}{ Ujung } & Excel & 3,5 & 0,088723 \\
\cline { 2 - 4 } & ANSYS & 0,914 & 0,02245 \\
\hline
\end{tabular}

Dengan perumusan perhitungan yang sama dengan model awal (teroptimasi), model th/tl=1 memiliki rasio tinggilebar yang berbeda dengan rasio optimal pada Ms.Excel. Berdasarkan tabel diatas, section pangkal dengan software hanya mengalami $5,27 \%$ optimal dari rasio optimalnya. Sedangkan pada section tengah dan ujung hasil software mencapai $70,2 \%$ dan $25,3 \%$ optimal dari rasio optimalnya pada perhitungan Ms.Excel.

Tabel 7

Perbandingan Rasio Tinggi-Lebar pada Jib Boom Model th/tl $>1$

\begin{tabular}{|c|c|c|c|}
\hline Section & $\boldsymbol{A N S Y S / \text { Excel }}$ & Rasio th/tl & $\mathbf{Z}=\mathbf{I} / \mathbf{c}$ \\
\hline \multirow{2}{*}{ Pangkal } & Excel & 4,3 & 0,0771 \\
\cline { 2 - 4 } & ANSYS & 0,41 & 0,0354 \\
\hline \multirow{2}{*}{ Tengah } & Excel & 4,1 & 0,108 \\
\cline { 2 - 4 } & ANSYS & 1,063 & 0,077 \\
\hline \multirow{2}{*}{ Ujung } & Excel & 4,4 & 0,0185 \\
\cline { 2 - 4 } & ANSYS & 0,91 & 0,0121 \\
\hline
\end{tabular}

Dengan model th/tl $>1$ hasil optimasi pada section pangkal hanya mencapai $45,9 \%$ optimal dari rasio optimal pada Ms.Excel. Sedangkan untuk section tengah mencapai 71,2\% optimal dari rasio optimal pada Ms.Excel. Rasio yang didapat dari hasil software 1,063, sedangkan rasio optimalnya adalah 4,1. Begitu pula dengan section ujung yang mencapai $65,4 \%$ optimal dari rasio optimalnya pada Ms.Excel. Rasio tinggilebar dari hasil optimasi software memberikan angka 0,91. Sedangkan pada rasio optimalnya adalah 4,4. 
Perbedaan hasil software dan Ms.Excel dikarenakan pada software batas bawah dan atas setiap variabel terbatas. Pada software, batas hanya dapat ditentukan dengan range tertentu. penentuan batas tidak bisa terlalu jauh dari geometri sebenarnya pada permodelan. pada software quality mesh yang digunakan hanya $23,8 \%$. hal ini bisa mempengaruhi hasil optimasi karena elemen yang kurang baik kualitasnya.

\section{KESIMPULAN/RINGKASAN}

Berdasarkan pembahasan pada penelitian ini, dapat ditarik kesimpulan

1. Berikut ini adalah kandidat poin baru (lebar $\mathrm{x}$ tinggi) setelah dilakukan optimasi pada jib boom hydraulic crane dengan:

a. Model awal teroptimasi $(10 \mathrm{~mm})$; untuk setiap sectionnya adalah $\mathrm{A}:(2 \times 0,89 \mathrm{~m}), \mathrm{B}:(2,1 \times 1,93 \mathrm{~m}), \mathrm{C}:(0,85 \times 0,88 \mathrm{~m})$.

b. Model th/tl=1 $(8 \mathrm{~mm})$; untuk setiap sectionnya adalah A:(2,26x1m), B: (2,36x2,1 m), C: (1,09x1 m).

c. Model th/tl $>1$ ( $\left.\mathrm{t}_{\mathrm{H}}: 12 \mathrm{~mm} ; \mathrm{t}_{\mathrm{L}}: 6 \mathrm{~mm}\right)$; untuk setiap sectionnya adalah A:(2x0,819 m), B: (2,0681x2,2 m), C: (0,9x0,819 m).
2. Dari ketiga model (Model awal teroptimasi, th/tl=1, th/tl $>1$ ) geometry mass paling ringan adalah model th/tl=1. Model ini memiliki equivalent stress yang berada dalam batas kekuatan material

\section{UCAPAN TERIMA KASIH}

Penulis Diaz Vidya Kelana mengucapkan terima kasih kepada Bapak Wanya dan Bapak Putu Rustika selaku Direktur Utama dan Design Engineer dari PT.Lelangon, sehingga penulis bisa menyelesaikan penelitian ini.

\section{DAFTAR PUSTAKA}

[1] O. de Wec, Design, Analysis and Optimization of Overhead Crane Girder. Vadasma, 2004.

[2] H. Raditya, "Analisa Gaya Pada Telescopic Boom Truck Crane XCMG QY50K," Surakarta, 2017.

[3] A. Pingle, "Size And Shape Optimization of An Excawation Boom Assembly," India, 2004.

[4] J. Singh, Introduction To optimum Design, 4th ed. Iowa: The university of Iowa, College of Engineering. 